\title{
Which Biomarkers Help to Distinguish Between Candida and Aspergillus in Patients with Pulmonary Infections?
}

\author{
다 Armağan Fatma Hazar, (1) Hatice Türker
}

\section{Department of Chest Diseases, University of Health Sciences \\ İstanbul Süreyyapaşa Chest Diseases and Thoracic Surgery Training and Research Hospital, İstanbul, Turkey \\ Submitted: 19.06.2018 Accepted: 13.08.2018 \\ Correspondence: Armağan Fatma Hazar, SBÜ İstanbul Süreyyapaşa Göğüs Hastalıkları ve Göğüs Cerrahisi Eğitim ve Araştırma Hastanesi, İstanbul, Turkey \\ E-mail: armaganhazar@yahoo.com}
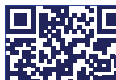

口ifts

Keywords: Aspergillosis, candidiasis; mean platelet volume; neutrophil-tolymphocyte ratio; platelet count/mean platelet volume; pulmonary fungal infection.

\begin{abstract}
Objective: This study was an evaluation of differences in the inflammatory markers of Creactive protein (CRP) level, the neutrophil-to-lymphocyte ratio (NLR), the platelet countto-mean platelet volume ratio (PLT/MPV), and the platelet-to-lymphocyte ratio (PLR) in patients with pulmonary candidiasis and pulmonary aspergillosis.
\end{abstract}

Methods: A retrospective, cross-sectional study was performed with the data of patients who were diagnosed with pulmonary candidiasis and pulmonary aspergillosis between 2016 and 2017 according to the records of the hospital information system. The results and date of hemograms, the biochemistry values, and C-reactive protein (CRP) levels were recorded. The NLR, PLT/MPV, and PLR were calculated. The documented parameters of the study groups were compared and analyzed.

Results: There were 44 patients ( 29 men) (candidiasis, $n=19$; aspergillosis, $n=25$ ), with a median age of 65 years. In both groups, the incidence of chronic obstructive pulmonary disease, level of CRP, and the NLR, PLR, MPV, and PLT/MPV were statistically similar. At discharge, the CRP, PLR, NLR, and PLT values were still similar in the 2 groups; however, the MPV was significantly lower in the pulmonary aspergillosis group when compared with the pulmonary candidiasis group (7.3 vs $8.4 ; \mathrm{p}=0029)$.

Conclusion: Most biomarkers were similar in the pulmonary aspergillosis and the candidiasis groups; however, a PLT elevation and an MPV decrease were significant in the diagnosis of aspergillus. Similar findings in prospective, multicenter studies performed with patients who are suspected of having a fungal lung infection will add to the ultimate determination of the value to be given to PLT and MPV biomarkers in the initiation of empirical treatment.

\section{INTRODUCTION}

Fungal infections of the respiratory system are diseases with a high rate of mortality and morbidity. They often present in immunosuppressed patients. ${ }^{[l]}$ Early diagnosis and early initiation of treatment in fungal infections markedly reduces morbidity and mortality. ${ }^{[2]}$ Candida spp. and Aspergillus spp. are primary agents of fungal infection in patients with parenchymal disease and sequelae, such as chronic obstructive pulmonary disease (COPD), interstitial lung disease, tuberculosis, and bronchiectasis, and in patients with the chronic use of steroids or immunosuppressive drugs. ${ }^{[2]}$ Candida spp. are endogenous in the mucosa and may become pathogenic with antibiotics used to fight infectious disease. ${ }^{[3]}$

In respiratory system infections, the most important way to reduce mortality is to initiate treatment as soon as possible. Treatment differs between Candida and Aspergillus infections: As first-line antifungals, fluconazole has been used in cases of candidiasis, and the varicosanol group of drugs in Aspergillus infections. As treatment options, the echinocandin group of drugs has been used for candidiasis 
and amphotericin B for both Candida and Aspergillus infections. ${ }^{[2]}$ Among the known biomarkers, $C$ - reactive protein (CRP) and leukocyte counts do not aid the physician in the discrimination between Candida and Aspergillus infections, so new hemogram parameters, such as the neutrophil-to-lymphocyte ratio (NLR), platelet-to-mean platelet volume ratio (PLT/MPV), platelet-to-lymphocyte ratio (PLR), and procalcitonin level are being investigated for use in the discrimination between fungal and bacterial infections. ${ }^{[47]}$

At present, studies in the literature about the role of inflammatory markers in the fungal infections of Candida albicans and Aspergillus fumigatus are still insufficient. This study was an investigation of whether platelets, which are fragments of megakaryocytes, and NLR, PLR, MPV, and other hemogram subparameters could be used as an inflammatory biomarkers in Aspergillus and Candida infections.

\section{MATERIAL AND METHODS}

This study was constructed as a retrospective, crosssectional observational trial and conducted in the chest diseases and thoracic surgery department of the education and research hospital of a university. The study was approved by the Scientific Committee of the Hospital (14.05.2018 / 035) and ethical approval was granted based on compliance with the Helsinki Declaration. All of the study data were collected retrospectively from the hospital electronic information management system. The need to obtain informed consent from the patients for the use of medical data for publication was waived by the scientific committee due to the retrospective nature of the study in accordance with local legislation. The identity information of all patients was strictly protected.

\section{The patients}

Among patients receiving inpatient treatment between January I and December 3I, 20I6, those whose diseases were coded as pulmonary candidiasis (IDC B 37) or pulmonary aspergillosis (ICD B 44) according to the International Classification of Diseases 10th Revision, and who underwent a hematological examination at admission and prior to discharge were enrolled in the study. Patients who were classified as cases of colonization of fungal infection as described below were excluded from the study. Patients with etiological factors for non-fungal infections that could cause changes in inflammatory biomarkers were also excluded. Adult patients with a pulmonary infection that was considered to be a pathogenic agent of Candida or Aspergillus were included in the study. The definition of Candida and Aspergillus infections is provided below.

\section{Definitions}

Fungal colonization: Samples were harvested from different regions of the body and if the ratio of areas with intense growth of Candida spp. to areas with only general growth of Candida spp. were detected was greater than 0.4 in semiquantitive culture media, these areas were considered to be colonized and these patients were excluded from the study. ${ }^{\left[{ }^{[8]}\right.}$

Patients hospitalized in the intensive care unit, immunosuppressed patients, surgical patients, those receiving total parenteral nutrition, with a central venous catheter, a history of diabetes mellitus, severe sepsis, or prolonged mechanical ventilation were considered to be at risk for fungal infection. Fungal growth was accepted as a pathogenic condition..$^{[9]}$

Candidiasis: The presence of candidiasis was defined with Candida spp. detected in patients with clinical and radiological (plain pulmonary radiography and computed tomography) evidence of pulmonary infiltration and increased CRP and hemogram values, a microbiological examination that did not demonstrate growth of any pathogen other than Candida spp., immunosuppressed cases, patients who were using systemic steroids for more than 6 months, those who were hospitalized in the intensive care unit and using two or more antibiotics. ${ }^{[10,11]}$

Aspergillosis: The presence of clinical and radiological (pulmonary plain radiograph and computerized) evidence, infection parameters, and cases where no pathogenic organism other than Aspergillus spp. was detected in the sputum/bronchoscopy lavage/blood samples which could explain the infection was considered aspergillosis. ${ }^{[1-13]}$

\section{Diagnostic methods}

\section{Flexible bronchoscopy}

In our center, the presence of a whitish, sticky secretion and edematous hyperemic mucosa and/or mucosal plaque formation observed on bronchoscopy in patients with COPD, diabetes mellitus, or those using steroids is defined as a suspect tracheobronchial fungal infection (TBFI). ${ }^{[14]}$ The results of bronchial lavage and bronchial mucosal biopsy were recorded in cases of a suspected TBFI.

\section{Evaluation of microbiological material}

Bronchoscopic lavage: Bronchial and tracheal lavage material was inoculated on Sabouraud dextrose agar and a microbiological culture analyzer (mini API; Biomerieux, Marcy l'Etoile, France) was used to identify molds and yeasts. The distinction between Candida albicans and Candida non-albicans was not recorded. Aspergillus was also identified by inoculating bronchial and tracheal lavage 
material in Sabouraud's dextrose agar. Fast growing white, yellow, yellow-brown, brown-black, or green colonies were considered positive for aspergillosis. Bronchoscopic suspicion in patients based on clinical findings or the observance of growth of Candida spp. in deep tracheal aspirate or bronchoscopic lavage material was recorded as a diagnosis of pulmonary candidiasis, and galactomannan positivity seen in lavage material was used as a rapid method of diagnosis of pulmonary aspergillosis.

\section{Calculations}

Neutrophil-to-lymphocyte ratio (NLR): NLR as a marker of systemic inflammation was defined as the absolute number of neutrophils divided by the absolute lymphocyte count. ${ }^{[15,16]}$

Platelet-to-lymphocyte ratio (PLR): PLR was defined as the absolute platelet count divided by the absolute lymphocyte count. ${ }^{[16,17]}$

PLT-to-mean platelet volume ratio (PLT/MPV):
The PLT/MPV was the calculated value of the ratio of the platelet volume to the mean platelet volume. ${ }^{[18]}$

\section{C-reactive protein-to-serum albumin ratio (CAR):}

The CRP was divided by the serum albumin value to determine the CAR. ${ }^{[19]}$

\section{Recorded data}

Patient admission and discharge hemogram and subparameter data, as well as demographic characteristics, additional diseases, length of hospitalization, and hospital mortality details were recorded based on hospital records. CRP, NLR, PLT/MPV, and PLR values were calculated and recorded.

\section{Statistical analysis}

Statistical analyses were performed using the portable SPSS Statistics for Windows, Version 20.0 program (IBM Corp., Armonk, NY, USA). Patient demographics and clinical data were summarized using descriptive analysis. The Student's t-test was used for continuous variables, such

Table I. Demographic characteristics of pulmonary candidiasis and pulmonary aspergillosis groups

\begin{tabular}{|c|c|c|c|c|c|}
\hline & \multicolumn{2}{|c|}{ Pulmonary candidiasis $(n=19)$} & \multicolumn{2}{|c|}{ Pulmonary aspergillosis $(n=25)$} & \multirow[t]{2}{*}{$\mathbf{p}$} \\
\hline & $\mathbf{n}$ & $\%$ & $\mathbf{n}$ & $\%$ & \\
\hline Age median, years (IQR) & 19 & $66(54-79)$ & 25 & $61(55-73)$ & 0.39 \\
\hline Male & II & 58 & 18 & 72 & 0.020 \\
\hline \multicolumn{6}{|l|}{ Additional diseases } \\
\hline COPD & 8 & 42 & 10 & 40 & 0.89 \\
\hline Asthma & I & 5 & 1 & 4 & 0.84 \\
\hline Immune deficiency & 1 & 5 & 3 & 12 & 0.44 \\
\hline Hypertension & 3 & 16 & 0 & 0 & 0.040 \\
\hline Heart failure & I & 5 & 0 & 0 & 0.25 \\
\hline Malignancy & 1 & 5 & 2 & 8 & 0.72 \\
\hline \multicolumn{6}{|l|}{ Indications for hospitalization } \\
\hline Pneumonia & 20 & 80.0 & 15 & 78.9 & 0.93 \\
\hline COPD/Asthmatic episodes & 3 & 12.0 & 3 & 15.8 & 0.72 \\
\hline Bronchiectasis & 1 & 4.0 & 0 & 0.0 & 0.38 \\
\hline Hospital stay, median, days (IQR) & 19 & $8(7-12)$ & 25 & $5(2-6)$ & 0.009 \\
\hline \multicolumn{6}{|l|}{ Diagnostic methods } \\
\hline Bronchoscopic appearance, lavage/culture & 17 & 89.5 & 17 & 68.0 & 0.11 \\
\hline Surgical biopsy & 0 & 0.0 & 5 & 20.0 & \\
\hline Medical history and physical examination* & 2 & 10.5 & 3 & 12.0 & \\
\hline \multicolumn{6}{|l|}{ Hospitalization } \\
\hline In the service & 17 & 68.0 & 8 & 42.1 & 0.09 \\
\hline In the intensive care unit & 8 & 32.0 & II & 57.9 & \\
\hline Mortality & 2 & II & 2 & 8 & 0.77 \\
\hline
\end{tabular}

COPD: Chronic obstructive pulmonary disease, chi-square test; IQR: Interquartile range, Mann-Whitney $U$ test; *: Findings of oral candida mucositis, thrush on the epiglottis and surrounding area, history of respiratory fungal infection, ambulatory treatment follow-up in polyclinics with galactomannan positivity. 
as age, hemogram values, biochemistry values, NLR, PLR, PLT/MPV, and CRP when the distribution was normal. Values obtained using the Student's t-test were presented as mean $\pm S D$. The non-parametric Mann-Whitney $U$ test was used for non-normally distributed numerical values and the results were expressed as median value and interquartile range (IQR: $25 \%$ and $75 \%$ ). Dichotomic values, such as sex and the presence of additional disease, were tested with a chi-square test. A p value $<0.05$ was considered statistically significant.

\section{RESULTS}

A total of 44 (men: $n=29,66 \%$ ) patients with a median age of 65 years (IQR: 55-74 years) who were diagnosed with pulmonary aspergillosis $(n=25)$ or pulmonary candidiasis $(n=19)$, who had the appropriate hemogram values accessible in the hospital records, and who met the eligiblility criteria were included in the study.

The demographic characteristics of the participants, additional diseases present, and causes of hospitalization and mortality are summarized in Table I. A statistically significantly greater number of male patients were found in the pulmonary aspergillosis group, and the hospital stay was statistically significantly longer in the pulmonary candidiasis group.

Table 2 provides a comparison of hemogram values at hospital admission and discharge between patients with pulmonary candidiasis and those with pulmonary aspergillosis. Comparisons of leukocyte, erythrocyte, and other hemogram values between the 2 groups yielded similar results.

Biochemical values of glucose, creatinine, blood urea nitrogen, protein, albumin, electrolytes, lactate dehydrogenase (LDH), serum glutamic oxaloacetic transaminase, and serum glutamic pyruvic transaminase were also compared (Table 3). The LDH value measured at admission was significantly higher in patients with pulmonary candidiasis; however, the overall biochemical values measured at admission and discharge were similar between groups.

Inflammatory biomarkers were also analyzed at hospital admission and discharge (Table 4). The admission values were similar in both groups, while the discharge MPV value was significantly higher in the pulmonary aspergillosis group.

Figure I illustrates the MPV values of the patient groups compared with the normal range (MPV $<7.4 \mathrm{fL}$ ), and the platelet counts (PLT $>440.000 / \mathrm{mm}^{3}$ ) recorded at admission and discharge.

Table 2. Comparison of admission and discharge hemogram values of patients with pulmonary candidiasis and pulmonary aspergillosis

\begin{tabular}{|c|c|c|c|c|c|c|c|c|c|c|c|c|c|c|}
\hline & \multicolumn{7}{|c|}{ On admission } & \multicolumn{7}{|c|}{ At discharge } \\
\hline & \multicolumn{3}{|c|}{$\begin{array}{c}\text { Pulmonary } \\
\text { candidiasis } \\
(n=19)\end{array}$} & \multicolumn{3}{|c|}{$\begin{array}{l}\text { Pulmonary } \\
\text { aspergillosis } \\
\quad(n=25)\end{array}$} & \multirow[t]{2}{*}{$\mathbf{p}$} & \multicolumn{3}{|c|}{$\begin{array}{l}\text { Pulmonary } \\
\text { candidiasis } \\
(n=19)\end{array}$} & \multicolumn{3}{|c|}{$\begin{array}{l}\text { Pulmonary } \\
\text { aspergillosis } \\
\quad(n=25)\end{array}$} & \multirow[t]{2}{*}{$\mathbf{p}$} \\
\hline & Md. & $25 \%$ & $75 \%$ & Md. & $25 \%$ & $75 \%$ & & Md. & $25 \%$ & $75 \%$ & Md. & $25 \%$ & $75 \%$ & \\
\hline White blood cell count $\left(\times 10^{9} / \mathrm{mL}\right)$ & 9.7 & 7.4 & 15.8 & 10 & 8.5 & 13.4 & 13.8 & II.I & 8.7 & 13.6 & 10.8 & 8.4 & 13.8 & 0.89 \\
\hline Neutrophil count (x10\%/mL) & 8.8 & 5.7 & 12.1 & 7.8 & 5.9 & 10.5 & 1.0 & 8.2 & 6.2 & 11.8 & 8.8 & 5.5 & 11.5 & 0.92 \\
\hline Monocyte count $\left(\times 10^{9} / \mathrm{mL}\right)$ & 0.5 & 0.3 & 0.7 & 0.5 & 0.42 & 0.8 & 0.21 & 0.5 & 0.3 & 0.8 & 0.7 & 0.5 & 0.8 & 0.12 \\
\hline Lymphocyte count (x109/mL) & 1.0 & 0.7 & 1.9 & 1.5 & 0.8 & 1.8 & 0.43 & 1.2 & 0.8 & 2 & 1.1 & 0.94 & 2 & 0.82 \\
\hline Neutrophil (\%) & 79 & 71.7 & 86.9 & 75.55 & 66.15 & 87.9 & 0.34 & 80 & 73.02 & 88.4 & 81.8 & 66 & 87.8 & 0.90 \\
\hline Monocyte (\%) & 5.23 & 2.3 & 7.6 & 5.4 & 3.7 & 7.7 & 0.51 & 5.2 & 2.8 & 7.3 & 6 & 4.8 & 6.8 & 0.30 \\
\hline Lymphocyte (\%) & 10.9 & 5.7 & 17.2 & 13.1 & 5.7 & 21.5 & 0.69 & 13.2 & 7.2 & 19.8 & 9.36 & 7.7 & 22.3 & 0.91 \\
\hline Eosinophil (\%) & 0.57 & 0.1 & 1.9 & 0.9 & 0.2 & 1.4 & 0.38 & 0.7 & 0.1 & 1.42 & 0.4 & 0.1 & 1.2 & 0.97 \\
\hline Basophil (\%) & 0.3 & 0.1 & 1.1 & 0.3 & 0.2 & 0.7 & 0.89 & 0.2 & 0 & 0.4 & 0.2 & 0.1 & 0.5 & 0.81 \\
\hline Erythrocyte count $\left(\times 10^{9} / \mathrm{mL}\right)$ & 4.22 & 3.56 & 4.73 & 4.04 & 3.54 & 4.54 & 1.0 & 4.21 & 3.37 & 4.8 & 4 & 3.53 & 4.59 & 0.73 \\
\hline Hemoglobin cell count $\left(\times 10^{9} / \mathrm{mL}\right)$ & II.I & 10 & 13.4 & 12.4 & 9.6 & 13.6 & 0.78 & 11.4 & 9.4 & 13 & 11.6 & 9.3 & 13 & 0.93 \\
\hline Hematocrit cell count $\left(\times 10^{9} / \mathrm{mL}\right)$ & 34.7 & 29.7 & 39.4 & 38 & 29.1 & 40.5 & 0.62 & 34.3 & 28.9 & 38.9 & 34.5 & 30.2 & 38.9 & 0.90 \\
\hline Mean corpuscular volume & 83.7 & 78.7 & 89.2 & 86.2 & 84 & 88.8 & 0.33 & 83.7 & 79 & 88.9 & 86.7 & 83.9 & 89.3 & 0.18 \\
\hline Platelet distribution width & 17 & 16.7 & 17.8 & 17.2 & 16.98 & 17.5 & 0.85 & 17 & 16.5 & 17.5 & 17 & 16.8 & 17.5 & 0.72 \\
\hline RDW-CV & 17.67 & 15.4 & 19.4 & 15.8 & 14.7 & 17.5 & 0.16 & 17.77 & 15.3 & 19.5 & 15.5 & 15.1 & 17.9 & 0.14 \\
\hline
\end{tabular}


Table 3. Comparison of admission and discharge biochemical values of patients with pulmonary candidiasis and pulmonary aspergillosis

\begin{tabular}{|c|c|c|c|c|c|c|c|c|c|c|c|c|c|c|c|c|}
\hline \multicolumn{8}{|c|}{ On admission } & \multicolumn{9}{|c|}{ At discharge } \\
\hline \multicolumn{3}{|c|}{$\begin{array}{l}\text { Pulmonary } \\
\text { candidiasis }\end{array}$} & \multicolumn{4}{|c|}{$\begin{array}{l}\text { Pulmonary } \\
\text { aspergillosis }\end{array}$} & \multirow[t]{2}{*}{$\mathbf{P}^{*}$} & \multicolumn{4}{|c|}{$\begin{array}{l}\text { Pulmonary } \\
\text { candidiasis }\end{array}$} & \multicolumn{4}{|c|}{$\begin{array}{l}\text { Pulmonary } \\
\text { aspergillosis }\end{array}$} & $\mathbf{p}^{*}$ \\
\hline $\mathbf{n}$ & Md. $25 \%$ & $75 \%$ & $\mathbf{n}$ & Md. & $25 \%$ & $75 \%$ & & $\mathbf{n}$ & Md. & $25 \%$ & $75 \%$ & $\mathbf{n}$ & Md. & $25 \%$ & $75 \%$ & \\
\hline
\end{tabular}

Fasting blood glucose

$\begin{array}{lcccccccccccccccccc}\text { (mg/dL) } & 11 & 112 & 92 & 192 & 12 & 107 & 83 & 142 & 0.28 & 19 & 131 & 91 & 162 & 23 & 103 & 86 & 148 & 0.62 \\ \text { BUN }(\mathrm{mg} / \mathrm{dL}) & 17 & 44 & 25 & 81 & 16 & 33 & 22 & 47 & 0.28 & 19 & 36 & 23 & 71 & 23 & 33 & 25 & 64 & 0.82 \\ \text { Creatinine }(\mathrm{mg} / \mathrm{dL}) & 17 & 0.58 & 0.44 & 0.99 & 17 & 0.63 & 0.55 & 0.76 & 0.84 & 19 & 0.66 & 0.55 & 0.9 & 23 & 0.62 & 0.51 & 1 & 0.92 \\ \text { Protein }(\mathrm{mg} / \mathrm{dL}) & 5 & 6.2 & 6 & 6.2 & 5 & 7.5 & 6.8 & 7.6 & 0.08 & 13 & 5.8 & 5 & 6.4 & 14 & 6.6 & 5.5 & 7.2 & 0.29 \\ \text { Albumin }(\mathrm{mg} / \mathrm{dL}) & 9 & 3.5 & 3.1 & 3.6 & 14 & 3.1 & 2.5 & 3.7 & 0.73 & 18 & 3.3 & 2.3 & 3.6 & 22 & 3 & 2.6 & 3.5 & 0.49 \\ \text { Sodium }(\mathrm{mg} / \mathrm{dL}) & 17 & 138 & 134 & 140 & 16 & 136 & 131 & 139 & 0.33 & 19 & 137 & 134 & 142 & 23 & 137 & 133 & 140 & 0.65 \\ \text { Potassium }(\mathrm{mg} / \mathrm{dL}) & 17 & 4.5 & 3.9 & 4.8 & 15 & 4.6 & 4 & 4.9 & 0.42 & 19 & 4.2 & 3.9 & 4.9 & 22 & 4.3 & 4.1 & 4.6 & 0.65 \\ \text { Calcium }(\mathrm{mg} / \mathrm{dL}) & 12 & 9.1 & 8.6 & 9.3 & 13 & 8.9 & 8.2 & 9.3 & 0.46 & 18 & 8.8 & 8.2 & 9.4 & 21 & 8.6 & 8.4 & 9.1 & 0.70 \\ \text { LDH }(\mathrm{mg} / \mathrm{dL}) & 4 & 266 & 258 & 401 & 3 & 141 & 122 & 200 & 0.034 & 12 & 318 & 214 & 394 & 12 & 231 & 170 & 304 & 0.11 \\ \text { SGOT }(\mathrm{mg} / \mathrm{dL}) & 10 & 29 & 15 & 78 & 11 & 34 & 17 & 50 & 0.78 & 19 & 22 & 15 & 56 & 22 & 25 & 17 & 41 & 0.92 \\ \text { SGPT }(\mathrm{mg} / \mathrm{dL}) & 10 & 31 & 14 & 46 & 11 & 22 & 11 & 29 & 0.10 & 19 & 28 & 14 & 61 & 23 & 23 & 13 & 31 & 0.29\end{array}$

*Mann-Whitney U Test. Md.: Median; BUN: Blood urea nitrogen; LDH: Lactate dehydrogenase; SGOT: Serum glutamic oxaloacetic transaminase; SGPT: Serum glutamic pyruvic transaminase.

Table 4. Comparison of admission and discharge inflammatory biomarkers of patients with pulmonary candidiasis and pulmonary aspergillosis

\begin{tabular}{|c|c|c|c|c|c|c|c|c|c|c|c|c|c|c|c|c|c|c|}
\hline & \multicolumn{9}{|c|}{ On admission } & \multicolumn{9}{|c|}{ At discharge } \\
\hline & \multicolumn{4}{|c|}{$\begin{array}{c}\text { Pulmonary } \\
\text { candidiasis }(n=19)\end{array}$} & \multicolumn{4}{|c|}{$\begin{array}{c}\text { Pulmonary } \\
\text { aspergillosis }(n=25)\end{array}$} & \multirow[t]{2}{*}{$\mathbf{p}^{*}$} & \multicolumn{4}{|c|}{$\begin{array}{c}\text { Pulmonary } \\
\text { candidiasis }(n=19)\end{array}$} & \multicolumn{4}{|c|}{$\begin{array}{c}\text { Pulmonary } \\
\text { aspergillosis }(n=25)\end{array}$} & \multirow[t]{2}{*}{$\mathbf{p}^{*}$} \\
\hline & $\mathbf{n}$ & Md. & $25 \%$ & $75 \%$ & $\mathbf{n}$ & Md. & $25 \%$ & $75 \%$ & & $\mathbf{n}$ & Md. & $25 \%$ & $75 \%$ & $\mathbf{n}$ & Md. & $25 \%$ & $75 \%$ & \\
\hline CRP (mg/dL) & II & 70.8 & 1.8 & 140 & 7 & 30.3 & 7.8 & 74.1 & 0.56 & 19 & 15.3 & 8.5 & 113 & 20 & 19.6 & 3.1 & 48.7 & 0.51 \\
\hline PLR & 19 & 198.57 & 114.35 & 410 & 21 & 257.5 & 216 & 330 & 0.49 & 19 & 220.45 & 104.33 & 413.75 & 25 & 362.73 & 3153.7 & 528 & 0.40 \\
\hline IQR & 7 & 20.17 & 6.55 & 40.67 & 6 & 18.38 & 4.43 & 29.64 & 0.89 & 18 & 6.03 & 2.18 & 47.92 & 19 & 5.21 & 1.03 & 17 & 0.40 \\
\hline NLR & 19 & 7.11 & 4.38 & 1.13 & 21 & 5.83 & 3.17 & 15.56 & 0.62 & 19 & 5.9 & 3.75 & 11.45 & 25 & 9 & 2.93 & 11 & 0.90 \\
\hline PLT/MPV & 19 & 28.73 & 16.17 & 4.78 & 21 & 48.59 & 22.58 & 60.72 & 0.11 & 19 & 39.13 & 16.5 & 54.26 & 25 & 52.38 & 31.34 & 64.26 & 0.12 \\
\hline PLT & 19 & 259 & 152.6 & 394 & 21 & 324 & 210 & 424 & 0.19 & 19 & 279 & 170 & 355 & 25 & 399 & 257 & 47.2 & 0.19 \\
\hline MPV & 19 & 8.7 & 7.8 & 9.5 & 21 & 7.4 & 6.93 & 9.1 & 0.07 & 19 & 8.3 & 7.5 & 9.8 & 25 & 7.3 & 6.9 & 8.2 & 0.029 \\
\hline
\end{tabular}

*Mann-Whitney U Test. Md.: Median; CRP: C-reactive protein; IQR :CRP/albumin ratio; MPV: Mean platelet volume; NLR: Neutrophil-lymphocyte ratio; PLR: Platelet-lymphocyte ratio; PLT/MPV: Platelet-mean platelet volume ratio.

\section{DISCUSSION}

The NLR, PLR, and CRP values of patients with pulmonary candidiasis and pulmonary aspergillosis were similar; however, the MPV of the patients with pulmonary aspergillosis was significantly lower than the normal value $(<7.4 \mathrm{fL})$, and platelet counts were higher relative to pulmonary candidiasis patients.
Inflammatory biomarkers in fungal infections

\section{MPV, PLT/MPV}

Ates et al. ${ }^{[20]}$ reported that there was a significant difference in the MPV and MPV/PLT values between healthy subjects and patients with systemic inflammatory response syndrome (SIRS). In their study, they reported that there 


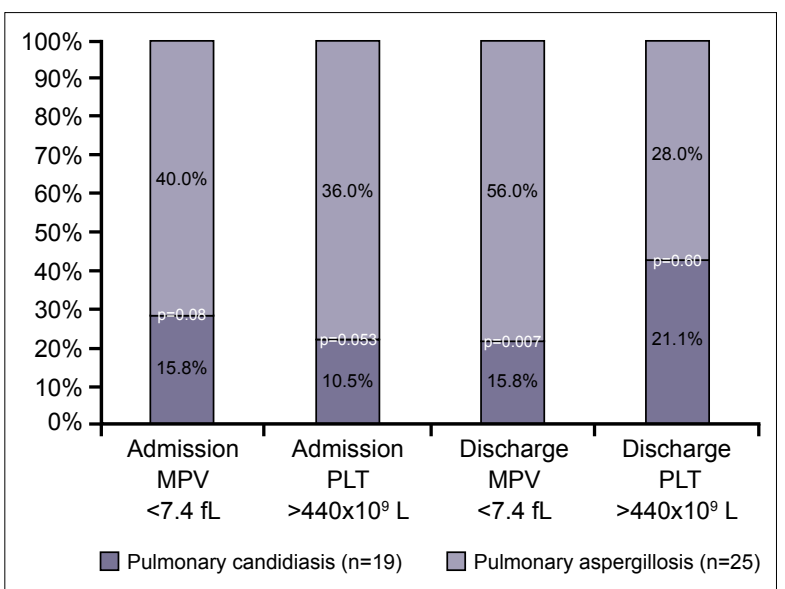

Figure 1. A comparison of the mean platelet volume (MPV) and platelet count (PLT) at admission and discharge in pulmonary candidiasis and pulmonary aspergillosis groups.

was no significant difference between the MPV values of SIRS and sepsis patients and that MPV values increased in sepsis patients. Zampieri et al. ${ }^{[21]}$ have demonstrated that the increase in MPV was proportional to the mortality rate in sepsis patients. Eser et al. ${ }^{[22]}$ found that platelet counts in sepsis patients were similar to the control group, suggesting that a reduction in the MPV value might be a diagnostic marker for pneumonia. In their study, infection among intensive care patients was markedly more severe. Though not statistically significant, a larger number of patients were hospitalized in the intensive care unit in the pulmonary aspergillosis group. The MPV values at admission and discharge were lower, but platelet counts were higher in the pulmonary aspergillosis group compared with the pulmonary candidiasis group, which was interpreted as the possible result of a bone marrow response due to an exogenous etiological infection agent.

There are studies showing that platelets are sensitive to stress, ischemia, obesity, hypoxia, and that smoking increases the activation of platelets. ${ }^{[23]}$ It has been also reported that chemokines and cytokines are secreted from the membranes of platelets and that they have a role in the immune response like that of acute phase reactants and thus exert antimicrobial activities. ${ }^{[22,24]}$

In their studies, Redlant ${ }^{[25]}$ and Speth ${ }^{[26]}$ demonstrated that Aspergillus spp. activate platelets, and that platelets act as antimicrobial and antifungal agents. An increased platelet count and a decreasing MPV may be considered an important finding in the differential diagnosis of fungal infections that suggests the diagnosis of aspergillosis rather than candidiasis.

\section{CRP, NLR, PLR}

The role of the inflammatory markers of CRP, NLR, leukocytes, and platelets have been investigated in the differential diagnosis between bacterial infections, Gram-pos- itive and Gram-negative infections, and fungal infections. [27-29] Ljungström et al. ${ }^{[27]}$ analyzed the levels of procalcitonin, CRP, NLR, and LDH in 1572 patients evaluated in the emergency service with the suspicion of sepsis, and reported that though these parameters were not significant markers, especially in the early diagnosis of sepsis, the NLR-procalcitonin and LDH-CRP combination could identify bacterial sepsis. In a recent, similar study, Miglietta et al. ${ }^{[28]}$ did not investigate fungi other than Candida, but studied the biomarkers of CRP, procalcitonin, platelet count, and LDH to differentiate between sepsis patients, patients with SIRS and systemic Candida infections among intensive care patients. Seventy patients with sepsis, 42 patients with SIRS, and 33 patients with systemic candidiasis were retrospectively enrolled in the study. The biomarkers were measured at intensive care admission and 2 days later. They found slightly lower CRP values $(60.5 \mathrm{mg} / \mathrm{L})$ in candidiasis patients when compared with those with Gram-negative (1 $12 \mathrm{mg} / \mathrm{L}$ ), and Gram-positive (184 mg/L) bacterial infections, while platelet counts were higher in patients with candidiasis. Pan et al. ${ }^{[29]}$ retrospectively investigated the use of the inflammatory markers of procalcitonin; leukocyte, neutrophil, and lymphocyte counts; NLR; CRP level; and platelet count in 1807 patients with chronic bacterial and fungal blood-borne infections. They reported that among 230 patients with bacterial growth in their blood cultures, higher procalcitonin, NLR, and neutrophil values were detected only in patients with Gram-negative infections when compared with those with Gram-positive, and that fungal infections were reliable biomarkers. In our study, in addition to other studies, higher platelet counts were seen in patients with aspergillosis relative to those with candidiasis. Unlike other studies, we also studied the PLR and CAR in the differential diagnosis between Candida and Aspergillus diagnoses, and no significant difference was found.

\section{Limitations}

There are some limitations to the study. Firstly, it was a single-center, retrospective study. However, patients data were retrieved from the hospital electronic system and data entry errors were minimized. The second limitation was the absence of fungal growth in tissue biopsy specimen in every case in order to identify the fungi. Although the diagnosis of fungal infection and fungal pneumonia is primarily made by demonstrating growth of fungi in the tissue culture material, ${ }^{[30]}$ due to difficulties encountered in diagnosing fungal infections, beta-D glucan was used for rapid diagnosis and the identification of Candida, and galactomannan was used for Aspergillus, ${ }^{[1]}$ in addition to clinical and microbiological results. In this study, we also indicated that the appearance of bronchoscopic material can be used in conjunction with microbiological results as a diagnostic tool in the identification of possible tracheo- 
bronchial fungal infections. ${ }^{[14]}$ As a third limitation, the results of the study cannot be generalized for any infection other than pulmonary candidiasis or aspergillosis.

\section{CONCLUSION}

Pulmonary candidiasis and pulmonary aspergillosis are common opportunistic fungal infections in COPD patients. The platelet count, MPV, and PLT/MPV estimated in pulmonary aspergillosis patients differ from those found in patients with pulmonary candidiasis. In patients with pulmonary aspergillosis, the platelet count and PLT/ MPV were higher, but the MPV value was lower relative to patients with pulmonary candidiasis. These findings may aid chest disease specialists in the discrimination between pulmonary candidiasis and pulmonary aspergillosis. Platelet count, MPV, and PLT/MPV values can be assessed with advanced diagnostic tests in patients at risk for pulmonary aspergillosis and their diagnostic values may be investigated in further studies.

Ethics Committee Approval

The study was approved by the Scientific Committee of the Hospital (14.05.2018 / 035) and ethical approval was granted based on compliance with the Helsinki Declaration.

Informed Consent

Retrospective study.

Peer-review

Internally peer-reviewed.

Authorship Contributions

Concept: F.A.H, H.T.; Design: F.A.H, H.T.; Data collection \&/or processing: F.A.H., H.T.; Analysis and/or interpretation: F.A.H., H.T.; Literature search: F.A.H., H.T.; Writing: F.A.H., H.T.; Critical review: F.A.H., H.T.

Conflict of Interest

None declared.

\section{REFERENCES}

1. Limper AH. Clinical approach and management for selected fungal infections in pulmonary and critical care patients. Chest 2014;146:1658-66. [CrossRef]

2. De Pascale G, Tumbarello M. Fungal infections in the ICU: advances in treatment and diagnosis. Curr Opin Crit Care 2015;21:421-9.

3. Ener S, Ener B, Akalın H. Deep candida infections that developed in intensive çare units after long operations [Article in Turkish]. Ege Tip Dergisi 2001;40:185-9.

4. Rødland EK, Ueland T, Pedersen TM, Halvorsen B, Muller F, Aukrust P, et al. Activation of platelets by Aspergillus fumigatus and potential role of platelets in the immunopathogenesis of Aspergillosis. Infect Immun 2010;78:1269-75. [CrossRef]

5. Heinekamp T, Schmidt H, Lapp K, Pähtz V, Shopova I, Köster-Eiserfunke $\mathrm{N}$, et al. Interference of Aspergillus fumigatus with the immune response. Semin Immunopathol 2015;37:141-52. [CrossRef]
6. Bruns S, Kniemeyer O, Hasenberg M, Aimanianda V, Nietzsche $\mathrm{S}$, Thywissen A, et al. Production of extracellular traps against Aspergillus fumigatus in vitro and in infected lung tissue is dependent on invading neutrophils and influenced by hydrophobin RodA. PLoS Pathog 2010;6:e1000873. [CrossRef]

7. Roques M, Chretien ML, Favennec C, Lafon I, Ferrant E, Legouge C, Plocque A, et al. Evolution of procalcitonin, C-reactive protein and fibrinogen levels in neutropenic leukaemia patients with invasive pulmonary aspergillosis or mucormycosis. Mycoses 2016;59:383-90.

8. Pittet D, Monod M, Suter PM, Frenk E, Auckenthaler R. Candida colonization and subsequent infections in critically ill surgical patients. Ann Surg 1994;220:751-8. [CrossRef]

9. Muskett H, Shahin J, Eyres G, Harvey S, Rowan K, Harrison D. Risk factors for invasive fungal disease in critically ill adult patients: a systematic review. Crit Care 2011;15:R287. [CrossRef]

10. Lindau S, Nadermann M, Ackermann H, Bingold TM, Stephan C, Kempf VA, et al. Antifungal therapy in patients with pulmonary Candida spp. colonization may have no beneficial effects. J Intensive Care 2015;3:31. [CrossRef]

11. Tessier JM. Infections in the Non-Transplanted Immunocompromised Host. Surg Infect (Larchmt) 2016;17:323-8. [CrossRef]

12. Atalay MA, Koç an, Sav H, Demir G. Antifungal Susceptibility of Aspergillus Species Isolated from Patients Diagnosed with Invasive Aspergillosis [Article in Turkish]. ANKEM Derg 2014;28:129-33.

13. Akan H. EORTC Definitions in Fungal Infections [Article in Turkish]. ANKEM Derg 2009;23:130-4.

14. Yazıcıoğlu Moçin O, Karakurt Z, Aksoy F, Güngör G, Partal M, Adıgüzel N, et al. Bronchoscopy as an indicator of tracheobronchial fungal infection in non-neutropenic intensive-care unit patients. Clin Microbiol Infect 2013;19:E136-41. [CrossRef]

15. Farah R, Ibrahim R, Nassar M, Najib D, Zivony Y, Eshel E. The neutrophil/lymphocyte ratio is a better addition to $\mathrm{C}$-reactive protein than CD64 index as a marker for infection in COPD. Panminerva Med 2017;59:203-9.

16. Unal D, Eroglu C, Kurtul N, Oguz A, Tasdemir A. Are neutrophil/ lymphocyte and platelet/lymphocyte rates in patients with non-small cell lung cancer associated with treatment response and prognosis? Asian Pac J Cancer Prev 2013;14:5237-42. [CrossRef]

17. Yoon NB, Son C, Um SJ. Role of the neutrophil-lymphocyte count ratio in the differential diagnosis between pulmonary tuberculosis and bacterial community-acquired pneumonia. Ann Lab Med 2013;33:105-10.

18. Nacaroglu HT, Erdem SB, Karaman S, Yazici S, Can D. Can mean platelet volume and neutrophil-to-lymphocyte ratio be biomarkers of acute exacerbation of bronchiectasis in children? Cent Eur J Immunol 2017;42:358-62. [CrossRef]

19. Ranzani OT, Zampieri FG, Forte DN, Azevedo LC, Park M. C-reactive protein/albumin ratio predicts 90 -day mortality of septic patients. PLoS One 2013;8:e59321. [CrossRef]

20. Ates S, Oksuz H, Dogu B, Bozkus F, Ucmak H, Yanit F. Can mean platelet volume and mean platelet volume/platelet count ratio be used as a diagnostic marker for sepsis and systemic inflammatory response syndrome? Saudi Med J 2015;36:1186-90. [CrossRef]

21. Zampieri FG, Ranzani OT, Sabatoski V, de Souza HP, Barbeiro H, da Neto LM, et al. An increase in mean platelet volume after admission is associated with higher mortality in critically ill patients. Ann Intensive Care 2014;4:20. [CrossRef]

22. Eser İ, Günay Ş, Sak ZHA, Yalçın F, Kürkçüoğlu İC. Mean Platelet 
Volume as a Diagnostic Indicator in Pneumonia Disease [Article in Turkish]. Tip Araştırmaları Dergisi 2014;12:12-4.

23. Guzmán-Grenfell A, Nieto-Velázquez N, Torres-Ramos Y, Montoya-Estrada A, Ramírez-Venegas A, Ochoa-Cautiño L, et al. Increased platelet and erythrocyte arginase activity in chronic obstructive pulmonary disease associated with tobacco or wood smoke exposure. J Investig Med 2011;59:587-92. [CrossRef]

24. Yalçın KS, Tahtacı G, Balçık ŞÖ. Role of platelets in inflammation. Dicle Medical Journal 2012;39:455-7. [CrossRef]

25. Rødland EK, Ueland T, Pedersen TM, Halvorsen B, Muller F, Aukrust $\mathrm{P}$, et al. Activation of platelets by Aspergillus fumigatus and potential role of platelets in the immunopathogenesis of Aspergillosis. Infect Immun 2010;78:1269-75. [CrossRef]

26. Speth C, Rambach G, Lass-Flörl C. Platelet immunology in fungal infections. Thromb Haemost 2014;112:632-9. [CrossRef]

27. Ljungström L, Pernestig AK, Jacobsson G, Andersson R, Usener B, Tilevik D. Diagnostic accuracy of procalcitonin, neutrophil-lympho- cyte count ratio, C-reactive protein, and lactate in patients with suspected bacterial sepsis. PLoS One 2017;12:e0181704. [CrossRef]

28. Miglietta F, Faneschi ML, Lobreglio G, Palumbo C, Rizzo A, Cucurachi $\mathrm{M}$, et al. Procalcitonin, $\mathrm{C}$-reactive protein and serum lactate dehydrogenase in the diagnosis of bacterial sepsis, SIRS and systemic candidiasis. Infez Med 2015;23:230-7.

29. Pan YP, Fang YP, Xu YH, Wang ZX, Shen JL. The Diagnostic Value of Procalcitonin Versus Other Biomarkers in Prediction of Bloodstream Infection. Clin Lab 2017;63:277-85. [CrossRef]

30. Kontoyiannis DP, Reddy BT, Torres HA, Luna M, Lewis RE, Tarrand J, et al. Pulmonary candidiasis in patients with cancer: an autopsy study. Clin Infect Dis 2002;34:400-3. [CrossRef]

31. Su KC, Chou KT, Hsiao YH, Tseng CM, Su VY Lee YC, Perng DW, et al. Measuring (1,3)- $\beta$-D-glucan in tracheal aspirate, bronchoalveolar lavage fluid, and serum for detection of suspected Candida pneumonia in immunocompromised and critically ill patients: a prospective observational study. BMC Infect Dis 2017;17:252. [CrossRef]

\section{Pulmoner Enfeksiyonu Olan Hastalarda Kandida ve Aspergillus Etken Ayrımında Hangi Biyobelirteçler Yardımcı Olur?}

Amaç: Çalışmada pulmoner kandidiaziz ve aspergilloziz enfeksiyonunda enflamatuvar belirteçlerden C-reaktif protein (CRP), nötrofil lenfosit oranı (NLO), platelet ve ortalama platelet hacmi (PLT/MPV), platelet lenfosit oranı (PLO) farklı olup olmadığı araştırıldı.

Gereç ve Yöntem: Çalışma 2016-2017 yıllarında geriye dönük kesitsel olarak yapıldı. Hastalar hastane bilgi yönetim sisteminden (HBYS) pulmoner kandidiaziz (ICD tanı kodu B 37), pulmoner aspergilloziz (ICD tanı kodu B44) kodu ile tarandı. Yatış, çıkış hemogramları, ek hastalıkları, yatış günü, hastane mortaliteleri kaydedildi. CRP, NLO, PLT/MPV, PLO hesaplandı. Grupların kayıt edilen değerleri, enflamatuvar biyobelirteçleri karşılaştırıldı.

Bulgular: Çalışmaya 44 (kandida $n=19$, aspergillus $n=25$ ) hasta alındı. Ortanca yaşları 65 ve 29 erkekdi (\%66). Pulmoner kandidiazis ve aspergilloziz hastalarında KOAH, hastaların yatış CRP, NLO, PLO, MPV, PLT/MPV değerleri benzer idi; taburculuk sırasında CRP, PLO, NLO, PLT benzer iken taburculukta MPV pulmoner aspergillozizde, pulmoner kandidiaziz hastalarından anlamlı düşük $(7.3$ ve 8.4, $p=0.029)$ idi.

Sonuç: Pulmoner aspergilloziz ve kandidiaziz enfeksiyonlarında çoğu biyobelirteç benzerdi. Aspergillus tanısında PLT yüksekliği ve MPV düşüklüğü anlamlıdır. Fungal akciğer enfeksiyonu düşünülen hastalarda yapılacak olan ileriye yönelik, çok merkezli çalışmalarda benzer bulgular olması amprik tedavi başlanmasında platelet ve MPV biyobelirteçlerinin önemini artıracaktır.

Anahtar Sözcükler: Aspergillus; kandidiaziz; nötrofil lenfosit oranı; ortalama platelet hacmi; platelet; platelet ortalama platelet hacmi; pulmoner fungal enfeksiyonlar. 